\title{
PENINGKATAN KEMAMPUAN BERHITUNG DENGAN METODE JARIMATIKA DI SEKOLAH DASAR NEGERI (SDN) NEONBAT NUSA TENGGARA TIMUR
}

\author{
Cecilia Novianti Salsinha, Eva Binsasi, Elinora Naikteas Bano \\ Universitas Timor, Kefamenanu, Indonesia \\ ceciliasalsinha@unimor.ac.id
}

\begin{abstract}
Abstrak: Salah satu metode pembelajaran yang cocok digunakan untuk operasi perkalian adalah metode jarimatika. Metode ini diberikan kepada siswa SD di Kefamenanu mengingat berdasarkan data Badan Pusat Statistik (BPS), Kefamenanu telah memiliki empat perguruan tinggi namun masih banyak siswa yang belum memiliki kemampuan berhitung cepat. Kelebihan metode jarimatika adalah tidak memerlukan alat peraga dan hafalan karena perhitungan dilakukan dengan memanfaatkan jari tangan sehingga diharapkan operasi hitung perkalian dapat lebih mudah dipahami, menyenangkan, dan tidak membebani memori otak siswa. Tujuan kegiatan pengabdian ini adalah untuk meningkatkan kemampuan berhitung siswa sekolah dasar. Kegiatan ini dilaksanakan di SDN Neonbat Kefamenanu, Nusa Tenggara Timur (NTT) dengan subyek pengabdian seluruh siswa kelas $\mathrm{V}$ yang berjumlah 60 orang. Pengabdian dilaksanakan dalam bentuk workshop yang dibagi menjadi 2 hari. Pelaksanaan hari pertama fokus pada review kemampuan dasar siswa yang meliputi perkalian 1-5 dan dilanjutkan dengan perkenalan teknik berhitung cepat dengan jarimatika untuk perkalian 6-10 dan 11-15. Pengabdian dilanjutkan pada hari kedua yaitu review materi pada hari sebelumnya dan penyampaian teknik berhitung cepat untuk kelompok 16-20 yang diakhiri dengan pemberian latihan. Kegiatan pengabdian tidak hanya berhenti pada workshop tetapi dilanjutkan dengan pendampingan terhadap siswa yang dipilih sebanyak 20 orang. Kegiatan pendampingan ini memberikan dampak positif terhadap hasil belajar yang diperoleh siswa. Hal ini dapat dilihat dari peningkatan nilai rata-rata pada pre-test sebesar 55,84 dan pada post test sebesar 75 .
\end{abstract}

Kata Kunci: berhitung cepat; metode jarimatika; perkalian; sekolah dasar

\begin{abstract}
One of the appropriate methods to learn multiplication is Jarimatika. It was given to elementary school students in Kefamenanu which, based on data from statistical central agency (BPS), has four colleges but there are still many students who do not have rapid counting skills. The advantage of this method is not requiring learning tools and memorization because calculations are done by utilizing the fingers so that the expected counting operation of multiplication can be more easily understood, enjoyable, and does not overload students'memory. The purpose of this community service program was to improve the counting skills of elementary school students. It was held at SDN Neonbat Kefamenanu, East Nusa Tenggara (NTT) involving $605^{\text {th }}$-grade students. The program was carried out in two-day workshop. The first day focused on the review of students ' basic ability which includes multiplication 1-5 and continued with the introduction of quick counting techniques with Jarimatika for multiplication 6-10 and 11-15. The second day was to review the previous day and introduce the rapid counting technique for multiplication 16-20. This program did not only end with the workshop but also continued with the assistance of 20 selected students. This assistance provided a positive impact on the results students get which can be seen from the increasing average score: 55,84 in the pre-test then increased to 75 in the post-test.
\end{abstract}

Keywords: fast counting; jarimatika method; multiplication; elementary school

\section{Pendahuluan}

Dalam pembelajaran matematika, khususnya berhitung tidak jarang ditemukan banyak kesulitan karena tidak banyak siswa yang tertarik dengan perhitungan (Charli, Amin, \& Agustina, 2018). Bukan hal yang mengherankan lagi ketika Matematika dianggap sebagai pelajaran paling 
sulit oleh siswa karena sebagian besar materinya memerlukan perhitungan. Anggapan inilah yang membuat siswa di sekolah tidak memiliki semangat untuk mempelajari Matematika. Disaat seperti ini, guru dituntut tidak hanya memilih metode pembelajaran yang sesuai dengan keadaan siswa sekarang tetapi juga mampu memilih strategi sehingga pembelajaran Matematika menjadi lebih menarik dan tidak membosankan (Suparni, 2015).

Upaya untuk mengajarkan matematika apalagi pada siswa SD bukanlah hal yang mudah. Hal ini menjadi tantangan tersendiri bagi guru yang mengajar oleh karena siswa masih berada pada tahap operasional konkrit. Artinya siswa akan menerima sesuatu yang mereka anggap konkrit atau nyata. Karso (2014) juga menyatakan bahwa Anak SD sedang mengalami perkembangan pada tingkat berpikirnya. Hal ini karena tahap berpikir siswa SD masih konkrit. Bahkan siswa SD di kelas rendah cenderung berada pada tahapan berpikir pra konkret. Sangat susah bagi siswa SD untuk menerima sesuatu yang abstrak. Namun disisi lain diketahui bahwa Matematika adalah ilmu yang abstrak dimana penuh dengan simbol (Suparni, 2015). Oleh karena itu kembali lagi tugas guru adalah menjembatani antara kenyataan yang dialami siswa dengan keabstrakan Matematika yang harus diajarkan ke anak didik.

Salah satu cara yang dapat dilakukan guru adalah menerapkan pembelajaran yang sesuai dengan karakteristik siswa seperti pemanfaatan alat peraga (Suparni, 2015). Alat peraga yang digunakan dapat berupa lidi, batu kerikil ataupun manik-manik sehingga memudahkan siswa dalam mempelajari matematika. Guru diharapkan dapat menanamkan konsep perkalian. Guru hendaknya tidak meminta siswa untuk menghafal karena pada dasarnya konsep perkalian adalah penjumlahan berulang bilangan yang sama (Wirasto dan Hirdjan, 1992). Mengingat perkalian merupakan operasi hitung yang sangat penting, sehingga menghafal bukan metode yang disarankan. Hal ini disebabkan karena selain daya ingat masing-masing siswa berbeda, menghafal dapat membuat siswa mudah lupa dengan hafalannya.

Namun seringkali guru lebih memilih metode metode konvensional yang mana membuat matematika menjadi tidak menarik untuk dipelajari. Salah satu penerapan metode konvensional dalam pembelajaran matematika khususnya dalam operasi hitung perkalian adalah siswa diberikan tugas untuk menghafal sejumlah perkalian misalkan perkalian 1 sampai dengan 5 kemudian pada pertemuan selanjutnya masing-masing siswa diminta untuk menyebutkan hafalan mereka di depan kelas. Hal ini akan sangat mudah bagi siswa yang rajin dan memiliki kemampuan menghafal yang bagus. Namun akan menjadi sangat sulit untuk siswa yang tidak memiliki kemampuan menghafal dengan baik akan sangat kesusahan jika diberikan tugas seperti ini. Pemberian tugas menghafal akan semakin memperkuat anggapan bahwa matematika itu merupakan pelajaran yang susah dan tidak menarik untuk dipelajari.

Salah satu metode pembelajaran yang cocok digunakan untuk berhitung khususnya untuk operasi perkalian adalah metode jarimatika. Indah (2015) menyatakan bahwa Metode jarimatika adalah metode belajar menggunakan jari tangan sebagai alat bantu operasi hitung bilangan yang biasanya disebut dengan istilah KaBaTaKu (Kali Bagi Tambah Kurang). Kelebihan metode ini selain tidak perlu memerlukan alat peraga yang perlu disediakan, siswa tidak diminta untuk menghafal karena perhitungan dilakukan dengan memanfaatkan jari tangan. Misalnya untuk mengoperasikan perkalian $5 \times 3$ maka dimisalkan jempol mewakili angka 1, jari telunjuk 
mewakili angka 2, jari tengah mewakili angka 3 dan seterusnya sampai kelingking mewakili angka 5. Selanjutnya karena dikali 3 maka setiap jari dihitung 3 ruas, sehingga jika ruas semua jari dijumlahkan akan menghasilkan 15 (jawaban dari perkalian $5 \times 3$ ). Penjelasan singkat ini memperlihatkan bahwa siswa ditekankan untuk memahami konsep sehingga diharapkan pembelajaran matematika terutama operasi hitung perkalian dapat lebih mudah dipamahi, lebih menyenangkan, asyik, menantang dan tidak membebani memori otak dengan hafalan. Yang lebih menyenangkan adalah karena dapat digunakan meski pada saat ujian karena alatnya sudah tersedia yaitu jari tangan siswa sendiri (Suparni, 2015).

Berdasarkan data Badan Pusat Statistik Kabupaten TTU (2016), Kabupaten Timor Tengah Utara (TTU), Nusa Tenggara Timur (NTT) khususnya data banyaknya sekolah berdasarkan tingkat pendidikan, TTU memiliki Taman Kanak-Kanak (TK) sebanyak 20, Sekolah Dasar (SD) sebanyak 267, Sekolah Lanjutan Tingkat Pertama (SLTP) sebanyak 90, Sekolah Lanjutan Tingkat Atas (SLTA) Umum sebanyak 29, Sekolah Menengah Kejuruan (SMK) sebanyak 18, dan Perguruan Tinggi/ Universitas/ Sekolah Tinggi/ Akademi sebanyak 4. Berdasarkan data tersebut, meskipun sudah banyak sekolah ataupun perguruan tinggi di Kabupaten Timor Tengah Utara, tapi masih sangat sedikit bahkan hampir tidak ada siswa ataupun mahasiswa yang mampu berhitung dengan cepat dan tepat (Ahzan, Binsasi dan Salsinha, 2018). Hal ini sangat memprihatinkan terutama karena kemampuan berhitung cepat sangat dibutuhkan terutama dalam ujian atau berbagai tes seperti TPA, tes CPNS dalam bentuk CAT.

Hasil penelitian Indah (2015) menyatakan bahwa metode jarimatika yang diberikan memberikan perbedaan hasil yang signifikan antara nilai pre-test dan post-test. Siswa memperoleh nilai yang lebih baik setelah diberikan teknik perhitungan dengan jarimatika. Hal senada juga dijelaskan oleh Sumirat (2016) bahwa metode jarimatika memberikan pengaruh positif terhadap keterampilan berhitung siswa. Berdasarkan hasil analisis diperoleh nahwa praktik jarimatika lebih berpengaruh dibandingkan dengan metode mencongkak.

Dengan adanya penerapan metode jarimatika diharapkan siswa, terlebih siswa usia dini seperti SD dapat dengan mudah memahami pelajaran matematika terutama operasi hitung perkalian sebagai bagian dari konsp dasar matematika. Selain itu metode ini diharapkan dapat mengubah anggapan siswa sejak dini bahwa matematika tidak menakutkan sebagaimana yang dipikirkan siswa dan sebaliknya memberikan anggapan bahwa mempelajari matematika adalah hal yang sangat menarik dan menyenangkan.

\section{Metode}

Kegiatan pengabdian ini dilaksanakan selama satu tahun anggaran 2019 yang dibagi menjadi dua bagian yaitu pemberian Workshop mengenai Teknik Berhitung Cepat dengan jarimatika yaitu pada bulan Juli 2019, selanjutnya dilakukan pendampingan terhadap perwakilan siswa yang telah mengikuti workshop dan dilakukan tes kemampuan berhitung dengan Jarimatika yang dilaksanakan pada bulan Agustus 2019. Pengabdian ini dilaksanakan di SDN Neonbat Kefamenanu. 
Berdasarkan definisi, Metode Jarimatika adalah suatu cara berhitung menggunakan jari dan ruas-ruas jari tangan (Wulandani, 2013). Dibandingkan dengan metode lainnya, metode Jarimatika lebih menekankan pada penguasaan konsep terlebih dahulu, kemudian cara cepatnya sehingga anak-anak dapat menguasai ilmu secara matang. Selain itu metode ini disampaikan kepada anak-anak dengan cara yang menyenangkan sehingga anak-anak merasa senang dan mudah untuk menerimanya (Elita, 2012). Berikut ini adalah formula dasar yang dapat digunakan untuk melakukan perkalian dengan Jarimatika (Prasetyono, 2010)

Tabel 1. Rumus Dasar Metode Jarimatika

\begin{tabular}{ccc}
\hline Kelas & Kelompok & Rumus Dasar \\
\hline 1 & $6-10$ & (Buka 1 + Buka 2) + (Tutup 1 x Tutup 2) \\
2 & $11-15$ & $100+($ Buka $1+$ Buka 2) + (Buka 1 x Buka 2) \\
3 & $16-20$ & $200+($ Buka 3 + Buka 4) + (Tutup 1 x Tutup 2) \\
\hline
\end{tabular}

\section{Keterangan:}

Buka 1 = Jari tangan kanan yang diBuka (Puluhan)

Buka 2 = Jari tangan kiri yang diBuka (Puluhan)

Buka 3 = Jari tangan kanan yang diBuka (dua Puluhan)

Buka 4 = Jari tangan kiri yang diBuka (dua Puluhan)

Tutup $1=$ jari tangan kanan yang diTutup (T1)

Tutup 2 = jari tangan kanan yang diTutup (T2)

Interpretasi dari formula pada tabel 1 adalah misalnya akan dilakukan perkalian $6 \times 8$. Jempol mewakili angka 6, telunjuk mewakili angka 7 dan seterusnya sampai kelingking mewakili angka 10. Hal yang sama terjadi pada tangan kiri maupun kanan. Untuk melakukan perkalian 6 x 8 maka tangan sebelah kiri akan membuka jempol sebagai perwakilan angka 6 dan pada tangan kanan jari yang dibuka adalah jempol, telunjuk dan jari tengah karena akan mewakili angka 6, 7 dan 8. Setelah itu, jari yang terbuka dimisalkan dengan 10 sehingga karena ada 4 jari yang dibuka maka jumlahnya adalah 40 . Jari yang tertutup pada tangan kiri ada 4 dan pada tangan kanan ada 2 sehingga dilakukan perkalian $4 \times 2$ yang hasilnya 8. Pada proses terakhir dilakukan penjumlahan 40 dan 8 sehingga hasil akhirnya adalah 48

Untuk meningkatkan kemampuan berhitung siswa melalui metode ini, maka langkahlangkah yang akan ditempuh adalah sebagai berikut :

1. Tahapan Persiapan

Pada tahap ini tim pengabdi melakukan kegiatan-kegatan sebagai berikut:

a. Melakukan koordinasi (pertemuan) dengan pihak sekolah, dalam hal ini Kepala Sekolah SDN Neonbat Kefamenanu, untuk mendiskusikan topik yang akan diabdikan

b. Mempersiapkan alat dan bahan meliputi persiapan perangkat pengabdian yaitu soal-soal pre-test dan post-test.

2. Tahapan Pelaksanaan.

a. Kegiatan workshop tentang Teknik Berhitung dengan Jarimatika dilaksanakan di SDN Neonbat Kefamenanu selama dua (2) hari. 
b. Dalam perkalian dengan menggunakan jarimatika, bilangan-bilangan pada operasi perkalian ini dibagi menjadi beberapa bagian yaitu kelompok I bilangan 1 sampai 6, kelompok II bilangan 11 sampai 20, kelompok 3 bilangan 21 sampai 30. Kelompok bilangan perkalian jarimatika ini sampai pada kelompok 5 yakni bilangan 40 sampai denga 50. Penyebutan bilangan pada masing-masing jari tidak selalu sama, bergantung pada kelompok-kelompoknya. Pada intinya proses perhitungan dengan jarimatika adalah sebagai berikut.

1) Dimulai dengan memahamkan secara benar mengenai konsep bilangan, lambang bilangan dan operasi hitung dasar. Pada tahap ini dilakukan semacam pre test mengenai operasi hitung dasar yang meliputi perkalian bilangan 1 sampai dengan 5 .

2) Setelah itu baru diajarkan bagaimana melakukan operasi hitung perkalian sesuai dengan pengelompokkan jarimatika.

Sebagai contoh akan dilakukan perkalian bilangan 6 sampai 10 (Formula yang digunakan sesuai dengan formula yang tertera pada tabel 1 ).

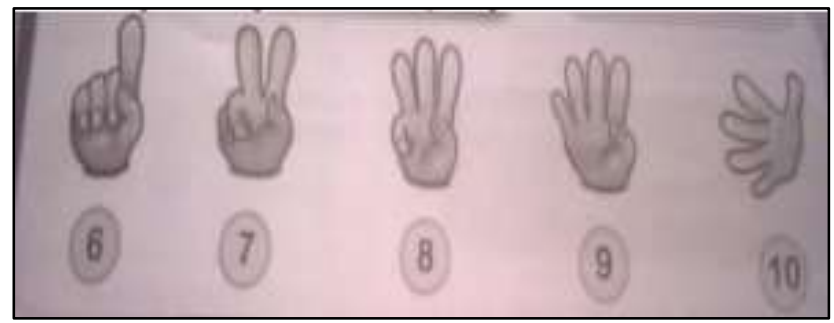

Gambar 1. Pemisalan angka 6 sampai 10 pada Tangan Kanan

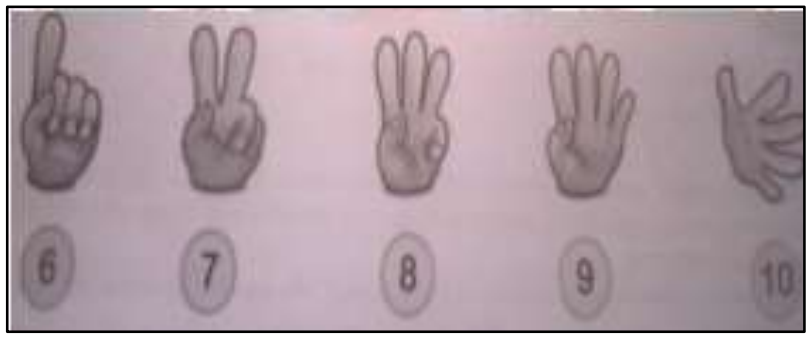

Gambar 2. Pemisalan angka 6 sampai 10 pada Tangan Kiri

Pada pengabdian ini dilakukan operasi hitung perkalian sampai pada kelompok 3 yaitu perkalian bilangan 15 sampai 20 oleh karena aturan kelompok 3 yang lebih rumit sehingga membutuhkan perhatian lebih dari siswa. Selain itu mengingat bahwa yang menjadi obyek pengabdian adalah siswa SD. Pada akhirnya diharapkan pengabdian ini dapat menambah wawasan siswa tentang cara berhitung dan dapat menerapkannya pada soal yang melibatkan perkalian yang sulit.

\section{Hasil dan Pembahasan}

Secara umum kegiatan dilaksanakan selama dua hari. Kegiatan pada hari pertama dibuka secara langsung oleh Kepala Sekolah SDN Neonbat dan dilanjutkan dengan proses review kembali mengenai perkalian 1-5. Proses review ini dilakukan untuk memastikan siswa memiliki pemahaman yang mendalam mengenai perkalian 1-5 sebelum diberikan teknik berhitung 
dengan jarimatika untuk perkalian 6-10. Setelah review selesai dilakukan, dilanjutkan dengan latihan yang mana terlihat dari hasil yang diperoleh yakni sebagian besar siswa telah paham mengenai perkalian 1-5 yang tidak melibatkan proses perkalian yang rumit.Kemudian dilanjutkan dengan pre test dan penjelasan mengenai teknik berhitung dengan jarimatika untuk kelompok 6-10 dan diakhiri dengan penjelasan mengenai jarimatika untuk kelompok perkalian 11-15. Masing-masing penjelasan diakhiri dengan latihan dan penyelesaian LKS. Workshop pada hari kedua diawali dengan penjelasan mengenai Jarimatika kelompok 16-20, dilanjutkan dengan latihan dan review mengenai jarimatika yang telah dipelajari pada hari sebelumnya. Workshop hari kedua berakhir pada pemberian LKS. Lebih lanjut kegiatan workshop ini tidak hanya berakhir pada workshop selama dua hari tetapi pengabdi melakukan kegiatan tindak lanjut sebulan setelah workshop diadakan untuk memberikan kesempatan kepada siswa untuk belajar dan menggunakan jarimatika dalam pembelajaran. Tindak lanjut diakhiri dengan pemberian post test setelah sebelumnya dilakukan review mengenai 3 kelompok perkalian yaitu 6-10, 1115 dan 16-20. Penjelasan lebih rinci akan dijelaskan dalam bagian-bagian pelaksanaan kegiatan sebagaimaa berikut.

\section{Pelaksanaan Hari Pertama}

Seperti telah dijelaskan sebelumnya bahwa workshop hari pertama diawali dengan pretest. Pre-test ini dikerjakan kurang lebih selama 30 menit untuk melihat kemampuan siswa sebelum diberikan penjelasan mengenai jarimatika 6-10. Workshop dilanjutkan dengan memberikan teknik berhitung cepat dengan jarimatika untuk perkalian 6-10. Proses ini diakhiri dengan latihan sekaligus membahas soal pre test yang telah diberikan sebelumnya. Selanjutnya diberikan penjelasan mengenai teknik perkalian 11-15. Pada perkalian 11-15 siswa mulai mengalami kesulitan jika dibandingkan dengan perkalian 6-10. Pada perkalian 11-15, sesuai dengan formula yang telah dijelaskan pada Tabel 1 lebih rumit dikarenakan siswa wajib menyimpan angka "100" untuk setiap perkalian yang dilakukan. Meskipun demikian, pengabdi berusaha menjelaskan secara perlahan sehingga siswa dapat memahami perkalian 11-15 terlebih ketika siswa harus berhadapan dengan soal yang menggunakan teknik yang berbeda. Siswa perlu membedakan kapan menggunakan jarimatika 6-10 dan 11-15 beserta teknik perhitungannya. Hasil pre-test disajikan dalam tabel 2 sedangkan rangkuman hasil secara deskriptif dapat dilihat pada tabel 3.

Tabel 2. Tabel Hasil Pre-test

\begin{tabular}{ccccccccc}
\hline Nama & Kelas & Nilai & Nama & Kelas & Nilai & Nama & Kelas & Nilai \\
\hline AI & VA & 51 & AKL & VB & 86 & APN & VC & 25 \\
ARFS & VA & 51 & ARS & VB & 30 & BK & VC & 0 \\
ATFH & VA & 38 & AS & VB & 19 & FAK & VC & 72 \\
DPL & VA & 26 & AA & VB & 58 & HIM & VC & 67 \\
EFB & VA & 58 & CNJA & VB & 79 & JL & VC & 88 \\
$\vdots$ & $\vdots$ & $\vdots$ & $\vdots$ & $\vdots$ & $\vdots$ & $\vdots$ & $\vdots$ & $\vdots$ \\
SWK & VA & 59 & YHMP & VB & 30 & RSS & VC & 44 \\
YAF & VA & 37 & YMK & VB & 30 & SADS & VC & 93 \\
$\bar{X}$ & 45.85 & $\bar{X}$ & 46.61111 & $\bar{X}$ & 60.21053 \\
$S$ & 14.25805 & $S$ & 22.65636 & $s$ & 25.982 \\
\hline
\end{tabular}


Tabel 3. Tabel Rangkuman Statistik Deskriptif Pre-test

\begin{tabular}{lr}
\hline \multicolumn{2}{c}{ Statistics } \\
\hline Pre-test & \\
$\mathrm{N} \quad$ Valid & 57 \\
\multicolumn{1}{c}{ Missing } & 0 \\
Mean & 50.8772 \\
Median & 51.0000 \\
Mode & 30.00 \\
Std. Deviation & $2.20503 \mathrm{E} 1$ \\
Variance & 486.217 \\
Range & 100.00 \\
Minimum & .00 \\
Maximum & 100.00 \\
Sum & 2900.00 \\
\hline
\end{tabular}

Hasil pada Tabel 3. menunjukkan bahwa rata-rata secara keseluruhan dari hasil Pre-test masih kecil yaitu sekitar 50, 8772. Hal ini menunjukkan bahwa kemampuan berhitung siswa kelas V SDN Neonbat masih kurang. Hal ini juga terlihat ketika siswa mengerjakan soal Pre-test bahwa banyak siswa belum mampu melakukan operasi perkalian. Pada tabel 3 juga terlihat bahwa Standar Deviasi data 22,0503 yang berarti bahwa masih ada kesenjangan yang cukup jauh antara siswa yang memperoleh nilai bagus dan yang kurang bagus, dapat dilihat dari range yang dihasilkan yaitu 100 dengan nilai maksimum 100 dan nilai minimum adalah 0 . Pada tabel 2. Dapat dilihat bahwa terdapat siswa yang memperoleh nilai 100 tetapi masih ada yang memperoleh nilai 30, 25 dan bahkan 0.Keadaan ini terlihat dari grafik sebagai berikut

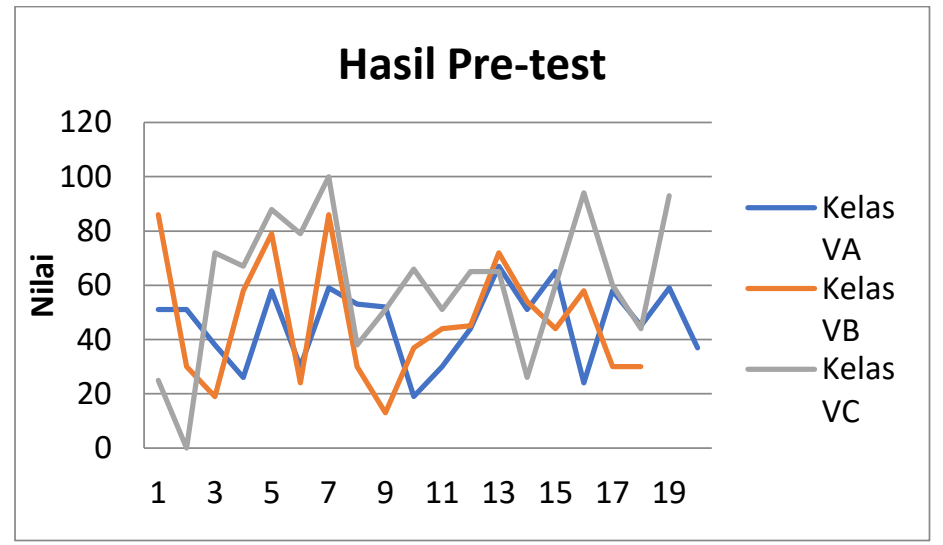

Gambar 3. Grafik Hasil Pre-test 3 Kelas

Hasil Pre-test pada grafik di atas memperlihatkan beberapa hal yaitu tidak banyak siswa yang memperoleh hasil pre-test di atas 70, bahkan dari kurang lebih 60 siswa, hanya 4 orang yang memperoleh nilai di atas 80 . Masih terdapat siswa yang memperoleh nilai dibawah 20. Hasil lain yang turut menguatkan kemampuan siswa tentang perkalian adalah pada Tabel 1 , Tabel 2 dan Tabel 3 di atas yang mana terlihat dari nilai rata-rata yang dihasilkan, nilai ratarata hanya berkisar antara 45-60. Standar deviasi yang dihasilkan juga beragam. Standar deviasi yang paling besar terdapat pada kelas $C$ yaitu 25.982 , hal ini menunjukkan bahwa meski nilai 
rata-rata kelas $\mathrm{C}$ paling tinggi, variasi data lumayan besar. Hal ini dapat dilihat pada Grafik nilai Pre-test, pada kelas C terdapat siswa yang memperoleh nilai 100 pada Pre-test tetapi nilai terendah juga terdapat pada kelas $\mathrm{C}$ dengan perolehan nilai Pre-test sebesar 0 . Beberapa hal yang telah dijelaskan menguatakan penulis untuk menyimpulkan bahwa kemampuan berhitung khususnya perkalian masih sangat kurang sehingga perlu ditingkatkan mengingat perkalian merupakan operasi hitung dasar yang wajib diketahui oleh semua siswa. Kegiatan hari pertama ini dapat dilihat pada gambar 4.

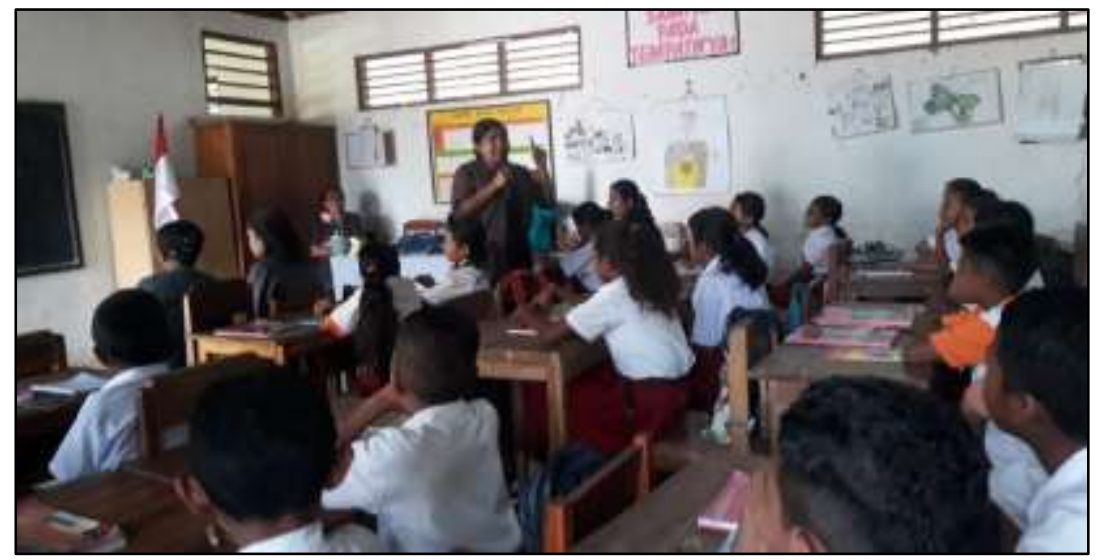

Gambar 4. Kegiatan Pengabdian Hari Pertama

Kegiatan hari I dilanjutkan perkalian dengan jari (jarimatika) untuk perkalian 6-10 dan setelah siswa diberikan penjelasan dan siswa mempraktekkan, siswa diberikan LKS untuk dikerjakan kemudian LKS dibahas bersama-sama.Selesai LKS dibahas kemudian siswa diberikan waktu 15 menit untuk beristirahat di luar ruangan.Kegiatan dilanjutkan dengan jarimatika untuk perkalian kelompok 11-15. Teknis pelaksanaannya sama dengan perkalian jarimatika 6-10.

\section{Pelaksanaan Hari Kedua}

Pada hari kedua workshop dilanjutkan dengan memberikan penjelasan kepada siswa mengenai jarimatika untuk kelompok 16-20. Workshop diawali dengan penjelasan mengenai jarimatika untuk kelompok 6-10 sampai jarimatika 11-15. Hal ini dilakukan untuk mengecek kemampuan siswa dalam mengingat materi yang telah diberikan sekaligus sebagai review sebelum dilanjutkan pada penjelasan mengenai jarimatika kelompok 16-20. Pada proses review ini terdapat beberapa siswa yang telah lupa cara menghitung dengan jarimatika, terutama jika diberikan soal secara acak perkalian 6-10 dan 11-15. Oleh karena itu proses review dilakukan lebih lama untuk menguatkan pemahaman siswa. Setelah proses latihan berlangsung sebagai bagian dari review, workshop dilanjutkan dengan penjelasan mengenai jarimatika kelompok 1620. Dalam menjelaskan jarimatika 16-20 siswa tampak mengalami kesulitan dalam memahami jarimatika oleh karena proses perhitungannya lebih sulit dibandingkan dua lainnya. Pengabdi memberikan LKS untuk latihan dan membahas satu per satu soal yang diberikan sehingga siswa lebih memahaminya. Kegiatan hari kedua berakhir. Kegiatan hari kedua ini dapat dilihat pada gambar 5 . 


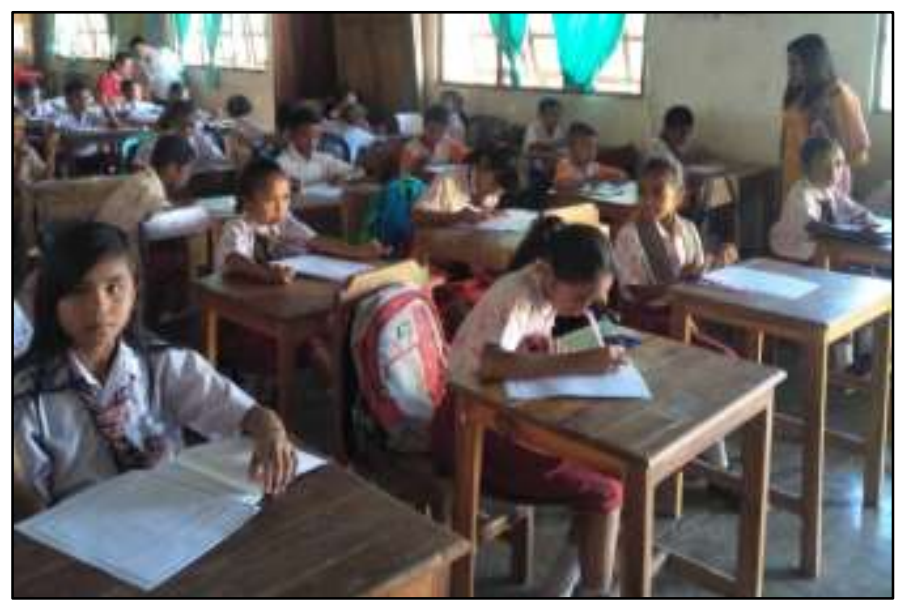

Gambar 5. Pengerjaan LKS pada hari Kedua

\section{Tahapan Tindak Lanjut}

Untuk memastikan siswa terus menggunakan metode ini digunakan terutama dalam operasi hitung perkalian maka dilakukan tahapan lanjutan.Tahapan ini dilakukan untuk mengecek perkembangan pemahaman siswa terkait perkalian dengan jarimatika.Pada tahap ini dari 60 siswa yang diambil 20 siswa untuk mengikuti kegiatan tindak lanjut. Kegiatan ini dilaksanakan selama dua hari yaitu tanggal 23 dan 24 Agustus 2019 dan pelaksanaannya kurang lebih satu bulan setelah kegiatan pertama dilakukan. Pelaksanaan tindak lanjut ini adalah sebagai berikut:

Tindak Lanjut Hari I: Tim pengabdi melakukan pengecekan dengan cara siswa mempraktekkan perkalian jarimatika 6-10, 10-15 kemudian diakhiri dengan pengecekan mengenai perkalian 16-20. Siswa yang kurang paham dberikan pendampingan sehingga mereka lebih paham lagi.Pada kegiatan tindak lanjut hari pertama ini oleh karena pengabdi memilih 20 orang peserta saja sehingga penjelasan lebih terarah. Masing-masing siswa didampingi secara personal sehingga peserta benar-benar bersemangat karena diperhatikan mulai dari proses perhitungan menggunakan jari sampai pada penjelasan dengan sesama siswa sebangku sebagai teman belajar. Kegiatan diakhiri dengan pemberian LKS untuk diselesaikan. Kegiatan tindak seperti pada gambar 6 .

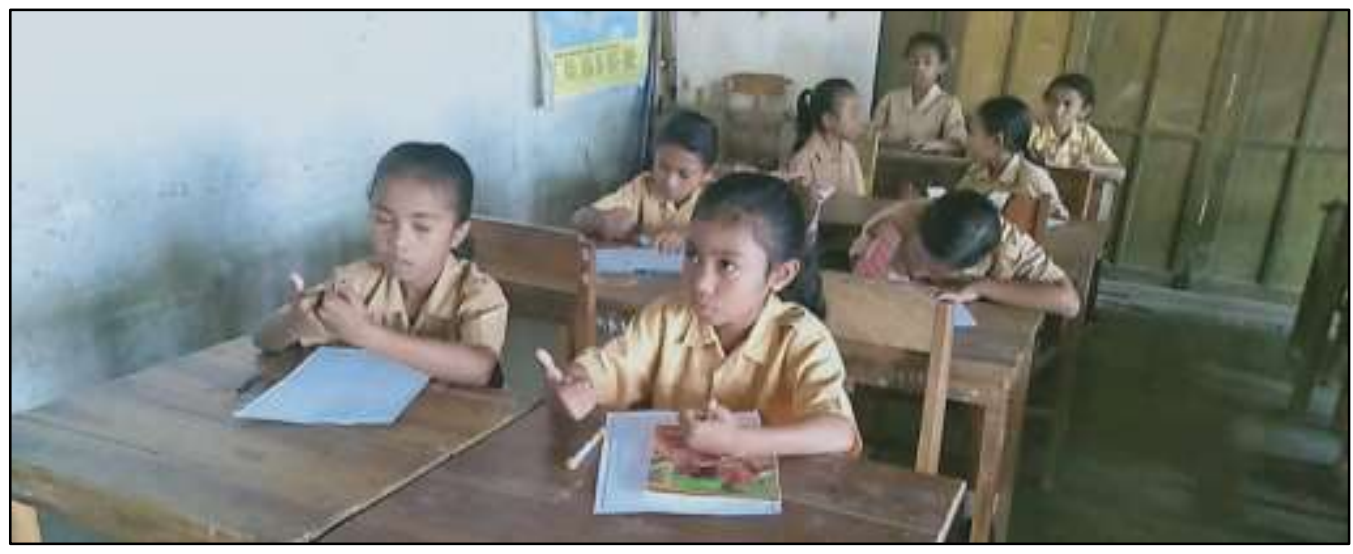

Gambar 6. Pengerjaan LKS pada Kegiatan Tindak Lanjut 
Tindak Lanjut Hari II: Pada hari kedua, siswa diberikan post-test. Hasil post-test tersaji dalam tabel 4. Sedangkan secara keseluruhan, rangkuman deskriptif statistic dari data Pre-test dan Post-test tersaji dalam tabel 5.

Tabel 4. Tabel Hasil Pre-test dan Post-test

\begin{tabular}{|c|c|c|c|}
\hline Nama & Kelas & Pre-test & Post-test \\
\hline AA & VB & 58 & 50 \\
\hline HIM & VC & 67 & 100 \\
\hline JFNF & VA & 44 & 70 \\
\hline $\mathrm{JL}$ & VC & 88 & 49 \\
\hline JJM & VC & 79 & 76 \\
\hline$\vdots$ & $\vdots$ & $\vdots$ & $\vdots$ \\
\hline OS & VC & 94 & 84 \\
\hline OGK & VC & 60 & 100 \\
\hline PML & VA & 0 & 84 \\
\hline RSS & VC & 44 & 69 \\
\hline SS & VA & 58 & 100 \\
\hline \multicolumn{2}{|r|}{$\bar{X}$} & 55.84 & 75 \\
\hline \multicolumn{2}{|r|}{$s$} & 24.61 & 18.806 \\
\hline
\end{tabular}

Tabel 5. Tabel Rangkuman Statistik Deskriptif Pre-test dan Post-test

\section{Statistics}

\begin{tabular}{|c|c|c|c|}
\hline \multirow{3}{*}{$N$} & & Pre-test & Post-test \\
\hline & Valid & 19 & 19 \\
\hline & Missing & 0 & 0 \\
\hline \multicolumn{2}{|c|}{ Mean } & 55.8421 & 75.0000 \\
\hline \multicolumn{2}{|c|}{ Median } & 58.0000 & 76.0000 \\
\hline \multicolumn{2}{|c|}{ Std. Deviation } & $2.46086 \mathrm{E} 1$ & 1.88060E1 \\
\hline \multicolumn{2}{|c|}{ Variance } & 605.585 & 353.667 \\
\hline \multicolumn{2}{|c|}{ Minimum } & .00 & 38.00 \\
\hline \multicolumn{2}{|c|}{ Maximum } & 100.00 & 100.00 \\
\hline \multicolumn{2}{|c|}{ Sum } & 1061.00 & 1425.00 \\
\hline
\end{tabular}

Berdasarkan hasil pada post-test terlihat bahwa nilai rata-rata siswa yang sebelumnya 55.8421 meningkat menjadi 75 yang sejalan dengan nilai median yang dihasilkan.Selain itu Standar deviasi yang sebelumnya 24.61 menurun menjadi 18.806. Standar deviasi yang dihasilkan menurun meski tak banyak. Hal ini menunjukkan bahwa rata-rata kelas meningkat dan data tidak lagi tersebar seperti pre-test. Meskipun pada post-test data terendah yang dihasilkan adalah 38 namun rangenya lebih sempit dibandingkan dengan data pre-test.Keadaan ini dapat dilihat pada gambar 7. 


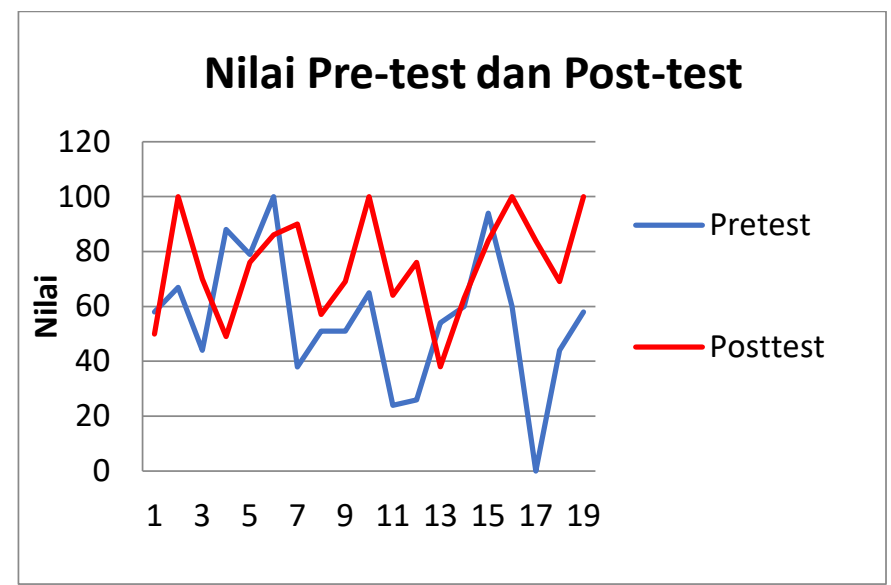

Gambar 7. Grafik Hasil Pre-test dan Post-test

Grafik nilai pre-test dan post-test yang telah ditampilkan menunjukkan bahwa kegiatan tindak lanjut membawa dampak positif bagi peningkatan hasil pada siswa SDN Neonbat Kefamenanu. Hal ini dibuktikan dengan nilai rata-rata yang semula sekitar 55.84 meningkat menjadi 75 dengan persebaran data yang mengecil yang dapat dilihat dari besaran standar deviasi yang dihasilkan. Selain itu juga dihasilkan range yang lebih sempit pada data post-test dibandingkan dengan data pre-test. Siswa juga menyatakan bahwa perkalian dengan Jarimatika ini awalnya susah tetapi ketika dipelajari dan diaplikasikan dalam pembelajaran, jarimatika lebih mudah dan menyenangkan. Hal ini sejalan dengan hasil penelitian yang dilakukan Bintaro dalam Rufiana, I., Wahyudi, W., \& Nurhidayah, D. (2019) yang menyatakan bahwa teknik Jarimatika ini mempermudah untuk belajar berhitung dan memperkenalkan Matematika khususnya kepada anak-anak bahwa Matematika (berhitung) itu menyenangkan. Selain memperhatikan perbedaan signifikan dari nilai pre-test dan post-tes yang dihasilkan, penelitian mengenai Efektivitas Jarimatika juga telah dilakukan oleh Salsinha, CN., Binsasi, E., \& Bano, EN. (2019) yang memberikan hasil bahwa metode jarimatika efektif digunakan untuk meningkatkan kemampuan berhitung siswa di Kefamenanu, NTT khususnya untuk materi perkalian.

\section{Kesimpulan}

Kegiatan Pengabdian ini memberikan dampak positif bagi siswa pada SDN Neonbat Kefamenanu. Hal ini dapat dilihat dari kenaikan signifikan antara pre-test dan post-test menunjukkan bahwa siswa benar-benar memperoleh peningkatan kemampuan berhitung setelah diberikan Workshop Teknik Berhitung dengan Jarimatika. Selain itu kegiatan ini lebih menyenangkan oleh karena siswa belum pernah diberikan metode Jarimatika untuk menghitung terutama perhitungan perkalian. Siswa merasa bahwa lebih mudah melakukan perkalian dengan metode Jarimatika karena perkalian dengan bilangan besar dapat disederhakan menjadi perkalian beberapa bilangan kecil yang lebih mudah untuk dipahami. 


\section{Ucapan Terima Kasih}

Penulis mengucapkan terimakasih kepada Universitas Timor, khususnya kepada LPPM Universitas Timor yang telah membiayai pengabdian ini. Ucapan terimakasih juga penulis sampaikan kepada Kepala Sekolah, Guru-guru terutama Guru Kelas V serta siswa-siswi SDN Neonbat Kefamenanu yang telah memperkenankan penulis melakukan pengabdian di SDN Neonbat. Semoga pengabdian ini bermanfaat bagi SDN Neonbat.

\section{Referensi}

Ahzan, Z. N., Binsasi, E., \& Salsinha, C. N. (2018). Workshop Teknik Berhitung Cepat Di Sekolah Dasar Negeri (Sdn) Sasi Kefamenanu Nusa Tenggara Timur. Dedication: Jurnal Pengabdian Masyarakat, 2(1), 17-26.

Charli, L., Amin, A., \& Agustina, D. (2018). Kesulitan Siswa Dalam Menyelesaikan Soal Fisika Pada Materi Suhu Dan Kalor Di Kelas X Sma Ar-Risalah Lubuklinggau Tahun Pelajaran 2016/2017. Journal Of Education and Instruction (JOEAI), 1(1), 42-51.

Elita, S. (2012). Efektivitas Metode Jarimatika Dalam Meningkatkan Kemampuan Perkalian Bagi Anak Kesulitan Belajar. Jurnal IImiah Pendidikan Khusus, 1(1), 23-34.

Indah, R. P. (2015). Efektivitas Metode Jarimatika Untuk Meningkatkan Kemampuan Berhitung Siswa Sekolah Dasar Kelas III. DutaCom Journal. 8(2): 1-7

Karso, H. (2014). Pendidikan Matematika 1. In: Pembelajaran Matematika di SD. Jakarta: Universitas Terbuka.

Prasetyono, Dwi Sunar, dkk. (2010). Pintar Jarimatika untuk SD, SLTP, SMU dan Umum. Yogyakarta: Diva Press.

Rufiana, I., Wahyudi, W., \& Nurhidayah, D. (2019). Optimalisasi mutu lulusan dengan pembekalan keterampilan berhitung model MARS (matematika dan aritmatika sederhana). Transformasi: Jurnal Pengabdian Masyarakat, 15(1), 44-52.

Salsinha, C.N., Binsasi, E., \& Bano, E.N. (2019). Efectiveness of Jarimatika Method to Improve Students' Counting Ability in Kefamenanu, East Nusa Tenggara. In National Conference on Mathematics Education, 1(1), 132-137.

Sumirat, I, Trimurtini, Wayuningsih. (2016). Pengaruh Praktik Jarimatika Terhadap Keterampilan Berhitung Perkalian Pada Siswa Kelas II SD. Jurnal Kreatif, 71 ), 63-72.

Suparni. (2015). Metode Jarimatika Kaitanya Dengan Pembelajaran Operasi Hitung Perkalian di SD/MI. Jurnal Logaritma, 3(1), 138-156.

Tim Penyusun. (2016). Banyaknya Sekolah, Guru dan Murid menurut Tingkat Pendidikan di Kabupaten Timor Tengah Utara. Katalog BPS: 1102001, 5303.

Wirasto dan Hirdjan. (1992). Matematika 1. Jakarta: Departemen Pendidikan dan Kebudayaan. Wulandani, S.P. (2013). Jarimatika Perkalian dan Pembagian. Jakarta: PT Kawan Pustaka. 